\title{
Pengaruh Intellectual Capital Dan Corporate Governance Terhadap Nilai Perusahaan Dengan Profitabilitas Sebagai Variabel Moderasi
}

\author{
Anisa Hediyanti Muasiri ${ }^{1}$, Erna Sulistyowati ${ }^{2}$ \\ ${ }^{1}$ UPN "Veteran" Jawa Timur, email: 17013010175@student.upnjatim.ac.id \\ 2UPN “Veteran” Jawa Timur, email: ernas.ak@upnjatim.ac.id
}

\section{ARTICLES \\ INFORMATION}

\section{ABSTRACT}

\section{JURNAL SEKURITAS \\ (Saham, Ekonomi, Keuangan dan Investasi) \\ Vol.4, No.3, Mei 2021 \\ Halaman : $275-285$ \\ C) LPPM \& Prodi Manajemen UNVERSITAS PAMULANG \\ ISSN (online) : 2581-2777 ISSN (print) : : 2581-2696}

\section{Keyword : \\ Intellectual Capital, Corporate Governance, Firm Value, Profitability}

JEL. classification :

C33, G21, G24, N15, N25

\section{Contact Author :}

PRODI MANAJEMEN UNPAM

JL.Surya Kencana No.1

Pamulang Tangerang Selatan Banten

Telp. (021) 7412566, Fax (021) 7412491 Email :

sekuritas@unpam.ac.id
Abstrak. Kajian ini dijalankan dengan tujuan untuk menguji pengaruh intellectual capital dan corporate governance pada nilai perusahaan dengan profitabilitas selaku variabel moderasi. Populasi pada kajian ini ialah perusahaan sektor perbankan yang tercatat di BEl periode 2015 - 2019 sebanyak 45 lembaga usaha. Tehnik yang digunakan dalam mengambil sampel yaitu dengan memakai purposive sampling maka didapatkan 15 sampel. Data sekunder berasal dari laporan setiap tahun serta laporan GCG lembaga usaha perbankan yang tercatat di BEl periode 2015 - 2019. Kajian ini memakai metode analisa data SEM-PLS dengan bantuan software WarpPLS 7.0. Hasil kajian ini memperlihatkan jika: (1) Intellectual capital memberi pengaruh positif dan signifikan pada nilai perusahaan, (2) Corporate governance tidak memberi pengaruh positif pada nilai perusahaan, (3) Profitabilitas bisa melakukan moderasi pengaruh intellectual capital pada nilai perusahaan, (4) Profitabilitas tidak bisa melakukan moderasi pengaruh corporate governance pada nilai perusahaan.

Abstract. This study aims to run a test on the influence of intellectual capital and corporate governance on the value of a business institution with profit as the moderating variable. Banking institutions listed on IDX during 2015 - 2019 period are the population in this study IDX, amounted to 45 companies. Sampling techniques using purposive sampling so that research samples obtained 15 companies Secondary data is the type of data used in this paper obtained from annual report and GCG report of Banking institutions listed on IDX during 2015 - 2019 period. Data analysis technique is SEMPLS using WarpPLS 7.0 software. The result show that: (1) Intellectual capital has positively and significantly effects on firm value, (2) Corporate governance has no effects on firm value, (3) Profitability can moderate the influence of intellectual capital on firm value, (4) Profitability cannot moderate the influence of corporate governance on firm value. 


\section{A. PENDAHULUAN}

Fenomena globalisasi yang dimulai pada awal abad ke-20 mengakibatkan perekonomian global semakin pesat berkembang. Adanya kemajuan ilmu pengetahuan dan kecanggihan teknologi informasi mampu melahirkan inovasi bisnis terbaru. Revolusi industri 4.0 tidak dapat dihindari lagi, seiring dengan perubahan dan kemajuan perekonomian dunia serta semakin terbukanya masyarakat modern dengan teknologi informasi serta ilmu pengetahuan. Hal tersebut memberikan dorongan perusahaan untuk semakin berfokus dalam knowledge assets selaku jenis aset yang tidak berbentuk atau intangible assets yang menjadi sumber baru kekuatan kinerja keuangan dan keunggulan kompetitif yang patut dibanggakan oleh perusahaan. Strategi bisnis perusahaan bergesar dari physical-based economy menjadi knowledge-based economy, sehingga perusahaan berfokus memperkuat ilmu pengetahuan dengan menggunakan manajemen pengetahuan (Soewarno \& Tjahjadi, 2020).

Penerapan knowledge management dalam suatu perusahaan akan membantu perusahaan dalam keefektifitas penggunaan aset yang lainnya, oleh karena itu bisa tercipta nilai tambah serta keunggulan kompetitif bagi lembaga usaha. Value added yang tercipta ini kemudian diistilahkan sebagai intellectual capital. Ini termasuk jumlah yang diperoleh dari tiga elemen yang paling mendasar yakni capital employed, human capital serta structural capital. Pengakuan dan pelaporan intellectual capital akan mendorong meningkatnya nilai perusahaan. Semakin tinggi nilai intellectual capital memperlihatkan jika semakin maksimal pengelolaan manajemen dalam suatu lembaga saya sehingga hal ini akan dijadikan sebagai aspek pertimbangan untuk para investor dalam memberikan nilai pasar yang tinggi bagi perusahaan (Sayyidah \& Saifi, 2017).

Selain adanya fenomena intellectual capital di tengah kompetisi bisnis global, setiap perusahaan mendapat tuntutan untuk mendapatkan citra yang baik dari para stakeholders. Selain mengoptimalkan pemanfaatan intellectual capital, perusahaan wajib memahami penggunaan corporate governance ataupun cara pengelolaan lembaga usaha. Corporate governance termasuk suatu hal yang menjadi penentu kesuksesan perusahaan dalam memberikan peningkatan keefisienan dan efektivitas pertumbuhan bisnis, meningkatkan kepercayaan investor dan melindungi kepentingan investor. Corporate governance diharap bisa memberi efek dalam meningkatkan kinerja perusahaan dengan mendorong para pihak investor untuk bisa melakukan penanaman modal Oleh karena itu memicu meningkatknya nilai perusahaannya (Suhadak et al., 2019).

Nilai perusahaan termasuk penilaian pihak yang akan berinvestasi pada kesuksesan suatu lembaga usaha dalam melakukan pengelolaan sumber daya yang dimiliki, dapat dilihat harga saham suatu lembaga usaha yang terdapat di pasar modal. Pasar modern memiliki peran yang vital pada perekonomian sebab menjadi sarana memperoleh dana dari masyarakat pemodal atau investor Kondisi pasar modal Indonesia di BEI terus berkembang dengan bertambahnya perusahaan yang melakukan perdagangan saham dan meningkatnya kesadaran masyarakat untuk berinvestasi saham di pasar modal (Arifardhani, 2020).

Perusahaan perbankan termasuk suatu sektor lembaga usaha yang tercatat di BEI. Lembaga perbankan menjadi salah satu saham dengan kapitalisasi terbesar di BEI (www.idx.co.id). Hal tersebut disebabkan lembaga usaha perbankan merupakan sektor yang strategis untuk para pihak yang akan berinvestasi dalam menanamkan modal karena kinerja perusahaan perbankan akan selalu diawasi dan dijamin oleh pemerintah melalui $\mathrm{BI}$ dan OJK sehingga perusahaan perbankan senantiasa menjaga tingkat kesehatan bank dan kinerja perusahaan sesuai dengan peraturan yang dikeluarkan oleh regulator (Purnama \& Rikumahu, 2020).

Pemilihan perusahaan sektor perbankan dalam penelitian ini karena industri perbankan di Indonesia menghadapi tantangan berat dari persaingan global dengan 
munculnya digitalisasi perbankan yang menuntut dan menjadikan perusahaan perbankan sebagai industry yang paling intensif dalam penerapan intellectual capital (Soewarno \& Tjahjadi, 2020). Selain itu, penerapan corporate governance pada perusahaan perbankan sangat ketat karena diawasi oleh OJK dan BI (Purnama \& Rikumahu, 2020).

Sesuai dengan berbagai permasalahan yang sudah dijelaskan, Oleh karena itu akan dijalankan kajian mengenai permasalahan tersebut. Rumusan permasalahan yang akan dilakukan pembahasan pada kajian ini yakni:

1. Apakah Intellectual Capital berpengaruh terhadap Nilai Perusahaan?

2. Apakah Corporate Governance berpengaruh terhadap Nilai Perusahaan?

3. Apakah Intellectual Capital berpengaruh terhadap Nilai Perusahaan yang dimoderasi dengan Profitabilitas?

4. Apakah Corporate Governance berpengaruh terhadap Nilai Perusahaan yang dimoderasi dengan Profitabilitas?

Dengan melakukan kajian ini peneliti memiliki tujuan untuk dapat menguji dan mengetahui pengaruh intellectual capital dan corporate governance pada nilai perusahaan dengan profitabilitas mengapa variabel moderasi dalam lembaga usaha perbankan yang ada di BEI periode 2015 - 2019.

\section{B. KAJIAN LITERATUR}

\section{Resource-Based Theory}

Menurut Ulum (2017:23) Resource-Based Theory (RBT) memperlihatkan jika lembaga usaha mempunyai sumber daya yang mampu membuat lembaga tersebut mempunyai keunggulan kompetitif serta mempunyai kinerja yang bersifat jangka panjang yang optimal. Sumber daya yang ada serta dimiliki perusahaan harus diorganisir, dikombinasikan dan dimanfaatkan secara tepat sehingga terciptalah keunggulan kompetitif serta mengarahkan perusahaan untuk dapat meningkatkan produktivitas dan kinerja perusahaan secara keseluruhan (Davis \& Simpson, 2017).

Keunggulan kompetitif yang dimiliki perusahaan bisa memberikan peningkatan daya tarik pihak yang akan melakukan investasi untuk bisa menanamkan modal di perusahaan tersebut. Peningkatan jumlah investor tersebut bisa memberikan peningkatan harga saham perusahaan serta termasuk indikasi jika pasar memberi nilai yang baik untuk perusahaan. (Lestari \& Satyawan, 2019).

\section{Signaling Theory}

Signaling theory berfokus pada informasi penting yang dipublikasikan perusahaan yang dapat memengaruhi keputusan investasi para investor. Salah satu informasi yang dikeluarkan adalah laporan setiap tahunnya yang didalamnya terdapat informasi akuntansi pada laporan keuangan serta informasi akuntansi yang tidak berhubungan dengan laporan keuangan (Ulum, 2017:33).

\section{Stakeholder Theory}

Stakeholder theory menyebutkan jika perusahaan tidak hanya melakukan operasi untuk memenuhi keperluan internal perusahaan semata namun juga wajib memberi manfaat untuk berbagai pihak yang mempunyai kepentingan $\mathrm{m}$ (Ghozali dan Chariri dalam Devi, 2017) Tujuan dari teori ini yaitu memberikan bantuan kepada pihak manajer perusahaan dalam memahami lingkungan para pemangku kepentingan dan mengelola perusahaan dengan lebih efektif sehingga dapat meminimalkan kerugian yang dapat dialami oleh para pemangku kepentingan (Ulum, 2017:35). 


\section{Agency Theory}

Agency theory menjelaskan hubungan agensi yang terjadi karena tanggung jawab yang sesuai dengan kepentingan principal dimana principal sebagai pemilik modal tidak memiliki kemampuan dan keterampilan dalam mengelola perusahaan, sehingga memberikan kewenangan kepada agent untuk menjalankan aktivitas operasi perusahaan dan mengambil keputusan dalam setiap permasalahan yang berkaitan dengan operasional perusahaan yang telah ada pada perjanjian yang telah dilakukan kesepakatan bersama oleh kedua pihak (Safriliana et al., 2018).

Kedua belah pihak memiliki kepentingan yang berbeda, dimana principal hanya berfokus pada peningkatan laba sedangkan agent berfokus pada peningkatan bisnis perusahaan secara keseluruhan. Perbedaan kepentingan ini dapat memicu munculnya permasalahan pada pihak agen serta principal menimbulkan adanya agency cost (Annisya et al., 2016).

\section{Intellectual Capital}

Intellectual Capital ialahseluruh sumber daya tidak berwujud yang berkontribusi pada penciptaan value added perusahaan. Intellectual capital tidak hanya sebagai penggerak dan sumber daya yang penting dalam penciptaan nilai tambah dan perkembangan perusahaan yang berkelanjutan tetapi juga sebagai sumber inovasi dan kunci pertumbuhan laba (Chowdhury et al., 2019).

Intellectual capital ialah suatu pendekatan yang dipakai pada kajian serta pengukuran aset yang tidak berbentuk (Soewarno \& Tjahjadi, 2020). Dalam mengukur intellectual capital dilakukan pengembangan oleh Pulic dengan alat diukur VAIC ${ }^{\mathrm{TM}}$ (Value Added Intellectual Coefficient). VAIC ${ }^{\mathrm{TM}}$ terdiri dari 3 komponen yakni VACA, VAHU dan STVA (Sayyidah \& Saifi, 2017). Secara ringkas formula serta tahap penghitungan VAIC ${ }^{\text {TM }}$ ialah seperti berikut (Ulum, 2017):

a. Menghitung VA

VA = OUT - IN

Keterangan:

VA : Nilai Tambah

OUT : jumlah pendapatan

IN : Total seluruh beban, kecuali beban pegawai

b. Menghitung VACA

VACA adalah rasio CE terhadap VA perusahaan.

$\mathrm{VACA}=\mathrm{VA} / \mathrm{CE}$

Keterangan:

VACA : Value Added Capital Employed

CE : Capital employed yaitu total ekuitas

c. Menghitung Value Added Human Capital (VAHU)

VAHU adalah rasio HC terhadap VA perusahaan.

VAHU = VA/HC

Keterangan:

VAHU : Value Added Human Capital

HC : Human Capital yaitu total beban karyawan

d. Menghitung STVA

STVA adalah rasio SC terhadap VA

STVA $=$ SC/VA 
Keterangan:

STVA : Structural Capital Value Added

SC : Structural Capital yaitu diperoleh dari perhitungan VA - HC

e. Menghitung $\mathrm{VAIC}^{\mathrm{TM}}$

VAIC $^{\text {TM }}=$ VACA + VAHU + STVA

\section{Corporate Governance}

Corporate Governance termasuk seperangkat sistem yang memberikan pengaturan serta melakukan pengendalian lembaga usaha dengan tujuan untuk membuat nilai tambahan untuk seluruh pihak yang mempunyai kepentingan serta wujud pertanggungjawaban pengelola perusahaan kepada stakeholders (I. Putri \& Iramani, 2017).

Dalam penelitian ini corporate governance dilakukan proksi dengan memakai rasio nilai komposit yang berasal dari hasil self-assessment good corporate governance yang dijalankan perusahaan perbankan dalam mengukur kualitas penerapan corporate governance. Menurut surat yang diedarkan oleh OJK No. 13/SEOJK.03/2017, di dalamnya memastikan penggunaan lima prinsip dasar pengelolaan yang baik, lembaga perbankan wajib menjalankan penilaian sendiri dengan cara berkala dengan minimal mencakup 11 aspek penilaian penggunaan tata kelola (D. A. Putri \& Yuliandhari, 2020).

Tabel 1 Peringkat Nilai Komposit Self-Assessment GCG

\begin{tabular}{|c|c|}
\hline Peringkat Nilai & Predikat \\
\hline 1 & Sangat Baik \\
\hline 2 & Baik \\
\hline 3 & Cukup Baik \\
\hline 4 & Kurang Baik \\
\hline 5 & Tidak Baik \\
\hline
\end{tabular}

Sumber: Lampiran II SEOJK/No. 13/SEOJK.03/2017

Bank melalukan penilaian secara mandiri good corporate governance dengan menggunakan peringkat satu hingga lima. Urutan pada peringkat GCG yang lebih bagus yakni apabila angka yang diperoleh siapa yang bernilai tinggi maka penggunaan GCG dianggap tidak baik, namun apabila angka peringkatnya di dapat bernilai rendah maka penggunaan GCG dinilai baik.

\section{Nilai Perusahaan}

Sartono (2010:487) memberikan penjelasan jika nilai perusahaan merupakan nilai jual suatu lembaga usaha sebagai entitas usaha yang tengah melakukan operasi. Nilai perusahaan dalam kajian ini dilakukan pengukuran memakai indikator Tobin's $Q$ yang dilakukan pengembangan oleh James Tobin .Tobin's $Q$ diformulasikan seperti berikut (Nurhayati, 2017):

Sumber: (Nurhayati, 2017)

$$
\text { Tobin's } Q=\frac{M E+D E B T}{T A}
$$

\section{Profitabilitas}

Profitabilitas menjadi alat ukur kinerja lembaga usaha yang menunjukkan kompetensi perusahaan dalam menciptakan keuntungan pada kurun waktu tertentu. Tingkat profitabilitas dari suatu lembaga usaha ialah suatu usaha yang dilakukan pengukuran sesuai dengan perbandingan pada laba sesudah pajak dengan jumlah aset sebuah lembaga usaha. ROA termasuk salah satu rasio pada profitabilitas. Pengukuran rasio ROA sebagai berikut (Sayyidah \& Saifi, 2017):

$$
\text { ROA }=\frac{E A T}{\text { Tntal Asrats }}
$$




\section{METODOLOGI PENELITIAN}

Kajian ini ialah kajian kuantitatif sebab memakai data angka serta analisa statistik (Sugiyono, 2019:15). Objek penelitian ini adalah $\operatorname{VAIC}^{\mathrm{TM}}\left(\mathrm{X}_{1}\right), \mathrm{CG}\left(\mathrm{X}_{2}\right)$, Tobin's $\mathrm{Q}(\mathrm{Y})$ dan ROA (Z). Populasi dan subjek pada kajian ini ialah seluruh lembaga usaha sub sektor perbankan yang ada di BEl selama periode 2015 hingga 2019 dengan jumlah sebanyak 45 lembaga usaha. Teknik pengambilan sampelnya memakai teknik purposive sampling dengan kriteria seperti berikut:

Tabel 2 Kriteria Pemilihan Sampel Penelitian

\begin{tabular}{|l|c|}
\hline \multicolumn{1}{|c|}{ Kriteria Sampel } & Jumlah \\
\hline $\begin{array}{l}\text { Perusahaan sub sektor perbankan yang terdaftar di } \\
\text { BEI periode 2015 - 2019 }\end{array}$ & 45 \\
\hline $\begin{array}{l}\text { Perusahaan sub sektor perbankan yang tidak listing } \\
\text { di BEl sebelum tahun } 2015\end{array}$ & $(8)$ \\
\hline $\begin{array}{l}\text { Perusahaa sub sektor perbankan yang tidak masuk } \\
\text { dalam kategori papan utama }\end{array}$ & $(13)$ \\
\hline $\begin{array}{l}\text { Perusahaan sub sektor perbankan yang tidak } \\
\text { mempublikasikan laporan tahunan (annual report) } \\
\text { secara berturut - turut selama tahun 2015 - 2019 }\end{array}$ & $(2)$ \\
\hline $\begin{array}{l}\text { Perusahaan sub sektor perbankan yang tidak } \\
\text { melengkapi laporan tata kelola perusahaan dengan } \\
\text { informasi terkait hasil self-assessment good } \\
\text { corporate governance selama periode 2015 - 2019 }\end{array}$ & \\
\hline $\begin{array}{l}\text { Perusahaan sub sektor perbankan yang mengalami } \\
\text { kerugian selama periode 2015 - 2019 }\end{array}$ & $(4)$ \\
\hline Perusahaan Sampel & $(3)$ \\
\hline Periode Pengamatan & 15 \\
\hline Jumlah Data Penelitian & 75 \\
\hline
\end{tabular}

Sumber: Data diolah peneliti (2021)

Jenis data yang dipakai pada kajian ini yaitu data sekunder yang berasal dari laporan setiap tahun serta laporan GCG lembaga usaha perbankan yang didapatkan dari situs resmi BEI (www.idx.co.id) dan situs resmi setiap lembaga usaha perbankan. Metode yang dipakai untuk mengumpulkan data pada kajian ini yaitu studi kepustakaan serta dokumentasi.

Teknik analisa data pada kajian ini memakai Structural Equation Modelling - Partial Least Squares dengan memakai software WarpPLS 7.0. Analisa SEM-PLS yang di dalamnya terdapat berbagai tahapan seperti tahapan evaluasi tipe pengukuran, tahap evaluasi tipe struktural dan tahap uji hipotesa. 


\section{HASIL DAN PEMBAHASAN}

Teknik analisa SEM-PLS mencakup beberapa tahapan seperti tahapan evaluasi model pengukuran yang diuji dengan melihatbconstruct validity, tahapan evaluasi model struktural (inner model) yang bisa dilihat melalui nilai $R$-square dan $Q^{2}$, serta tahap uji hipotesis.

Hasil Evaluasi Model Pengukuran (Outer Model)

Tabel 3 Hasil Uji Validitas Konvergen

\begin{tabular}{|c|c|c|c|c|c|c|c|}
\hline & VAIC & CG & ROA & TOBINS_Q & ROA $^{*}$ VAIC & ROA $^{*}$ CG & $P$-Value \\
\hline VAIC & $\mathbf{1 , 0 0 0}$ & 0,000 & 0,000 & 0,000 & 0,000 & 0,000 & $<0,001$ \\
\hline CG & 0,000 & $\mathbf{1 , 0 0 0}$ & 0,000 & 0,000 & 0,000 & 0,000 & $<0,001$ \\
\hline ROA & 0,000 & 0,000 & $\mathbf{1 , 0 0 0}$ & 0,000 & 0,000 & 0,000 & $<0,001$ \\
\hline TOBINS_Q & 0,000 & 0,000 & 0,000 & $\mathbf{1 , 0 0 0}$ & 0,000 & 0,000 & $<0,001$ \\
\hline ROA ${ }^{*}$ VAIC & 0,000 & 0,000 & 0,000 & 0,000 & $\mathbf{1 , 0 0 0}$ & 0,000 & $<0,001$ \\
\hline ROA $^{*}$ CG & 0,000 & 0,000 & 0,000 & 0,000 & 0,000 & $\mathbf{1 , 0 0 0}$ & $<0,001$ \\
\hline
\end{tabular}

Sumber: Data Diolah Peneliti (2021)

Menurut tabel 3 bisa dipahami bahwa setiap indikator memiliki nilai faktor loading sebesar 1,000 yang dapat dilihat pada kolom diagonal dari kanan atas ke kiri bawah. Nilai tersebut telah memenuhi ketentuan indicator reliability yang memiliki nilai $>0,70$. Hal ini dapat diartikan data telah valid dengan memenuhi batas kriteria yang telah ditentukan.

Tabel 4 Hasil Uji Validitas Diskriminan

\begin{tabular}{|c|c|c|c|c|c|c|}
\hline & VAIC & CG & ROA & TOBINS_Q & ROA VAIC & ROA ${ }^{*}$ CG \\
\hline AVE & 1,000 & 1,000 & 1,000 & 1,000 & 1,000 & 1,000 \\
\hline
\end{tabular}

Sumber: Data Diolah Peneliti (2021)

Berdasarkan tabel 4 diketahu jika AVE pada setiap indikator memiliki nilai 1,000 yang berarti telah memenuhi ketentuan nilai AVE harus lebih dari 0,50. Hal tersebut memperlihatkan Jika data sudah valid untuk dilakukan uji tahap selanjutnya.

Tabel 5 Hasil Uji Reliabilitas

\begin{tabular}{|c|c|c|}
\hline & Composite Reliability & Cronbach's Alpha \\
\hline VAIC & 1,000 & 1,000 \\
\hline CG & 1,000 & 1,000 \\
\hline ROA & 1,000 & 1,000 \\
\hline TOBINS_Q & 1,000 & 1,000 \\
\hline
\end{tabular}

Sumber: Data Diolah Peneliti (2021)

Sesuai tabel 5 memperlihatkan jika nilai uji reliabilitas pada composite reliability dan cronbach's alpha mempunyai nilai sebesar 1,000 ataupun lebih dari 0,70. Dapat disimpulkan syarat dari hasil evaluasi outer model sudah terpenuhi. 


\section{Hasil Evaluasi Model Struktural (Inner Model)}

Tabel 6 Hasil Inner Model

\begin{tabular}{|c|c|c|c|}
\hline & Nilai $R$-Square & Nilai Adjusted $R^{2}$ & Nilai $Q^{2}$ \\
\hline TOBINS_Q & 0,351 & 0,314 & 0,347 \\
\hline
\end{tabular}

Sesuai dengan tabel 6 bisa dipahami jika nilai $r$ square senilai 0,351 memperlihatkan model lemah serta memiliki arti bahwa TOBINS'Q $(Y)$ dapat dijelaskan atau dipengaruhi oleh VAIC $\left(X_{1}\right)$, CG $\left(X_{2}\right)$ dan ROA $(Z)$ sebesar $35,1 \%$. Nilai $Q^{2}$ sebesar 0,347 memiliki arti model memiliki predictive relevance dengan nilai observasi sebesar $34,7 \%$.

Tabel 7

Nilai Model Fit dan Quality Indices

\begin{tabular}{|c|c|c|}
\hline Indikator Fit Model & Indeks & $\boldsymbol{P}$-Value \\
\hline APC & 0,254 & 0,001 \\
\hline ARS & 0,351 & 0,018 \\
\hline AVIF & 2,218 & Acceptable if $<=5$ \\
\hline
\end{tabular}

Sumber: Data Diolah Peneliti (2021)

Berdasarkan tabel 7 menunjukkan nilai model fit pada penelitian ini yaitu $p-$ value untuk APC dan ARS adalah $<0,05$ serta AVIF $<5$, sehingga syarat fit model telah terpenuhi.

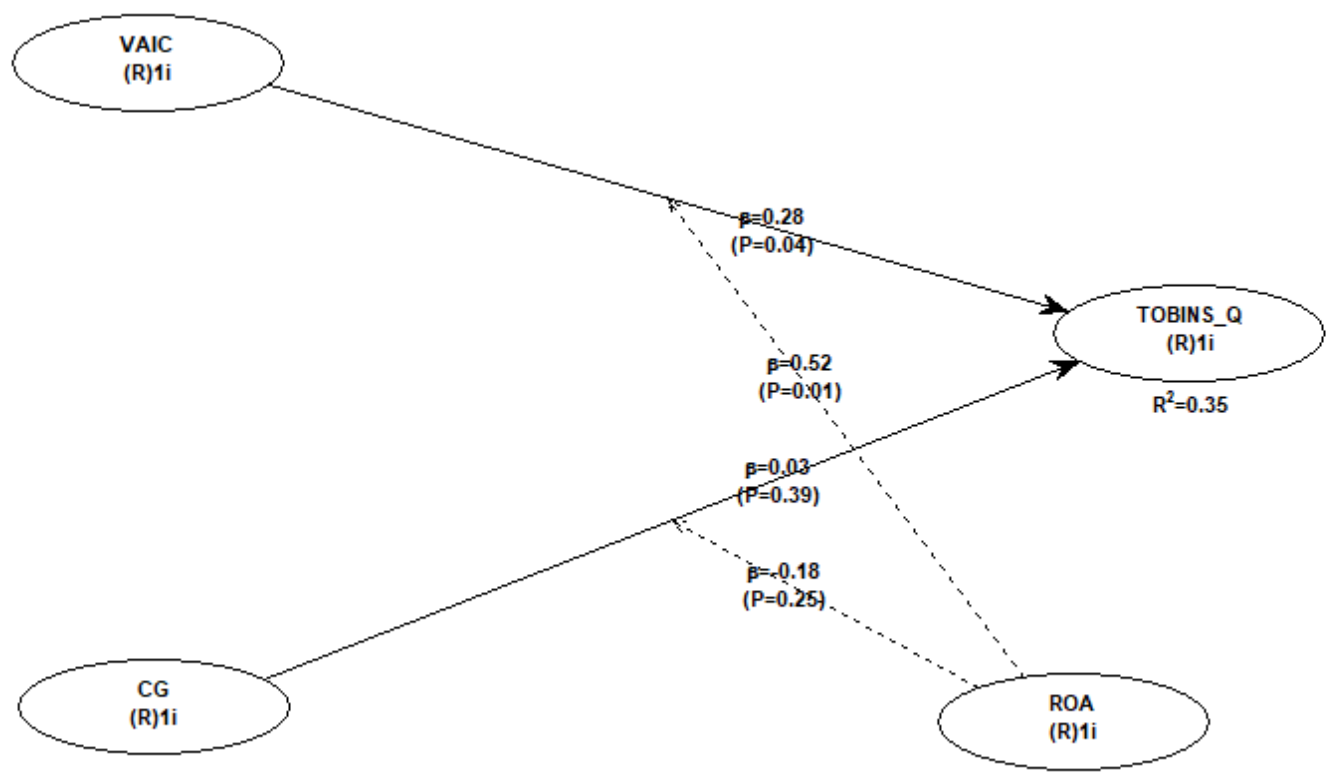

Sumber: Data Diolah Peneliti (2021) 
Gambar 1 Hasil Uji Hipotesis

Tabel 8 Hasil Uji Hipotesis Pengaruh Langsung

\begin{tabular}{|c|c|c|c|}
\hline Hipotesis & $\begin{array}{c}\text { Hubungan Antar } \\
\text { Variabel }\end{array}$ & Path Coefficient & P-Value \\
\hline Hipotesis 1 & VAIC $\rightarrow$ TOBINS_Q & 0.279 & 0.044 \\
\hline Hipotesis 2 & CG $\rightarrow$ TOBINS_Q & 0.033 & 0.391 \\
\hline
\end{tabular}

Sumber: Data Diolah Peneliti (2021)

Tabel 9

Hasil Uji Hipotesis Pengaruh Tidak Langsung

\begin{tabular}{|c|c|c|c|c|}
\hline Hipotesis & $\begin{array}{c}\text { Variabel } \\
\text { Moderasi }\end{array}$ & $\begin{array}{c}\text { Hubungan Antar } \\
\text { Variabel }\end{array}$ & $\begin{array}{c}\text { Path } \\
\text { Coefficient }\end{array}$ & $\boldsymbol{P}$ - Value \\
\hline Hipotesis 3 & ROA & VAIC $\diamond$ TOBINS_Q & 0.522 & 0.011 \\
\hline Hipotesis 4 & ROA & CG $\diamond$ TOBINS_Q & -0.183 & 0.249 \\
\hline
\end{tabular}

Sumber: Data Diolah Peneliti (2021)

Berdasarkan tabel 8 dan 9 dapat dijelaskan hasil pengujian sebagai berikut:

1. Variabel independen $X_{1}$ (VAIC) memberi pengaruh positif serta signifikan pada $Y$ (TOBINS'Q) karena nilai $p$-values senilai 0,044 yang lebih rendah dari 0,05 . Nilai path coefficients senilai 0,279 menunjukkan arah pengaruhnya positif.

2. Variabel independent $X_{2}$ (CG) tidak berpengaruh signifikan terhadap $Y$ (TOBINS'Q) karena nilai $p$-values senilai 0,391 dimana lebih tinggi dari 0,05.

3. ROA memoderasi pengaruh $X_{1}$ (VAIC) terhadap $Y$ (TOBINS'Q) karena nilai $p$-values senilai 0,011 yang lebih kecil dari 0,05 . Nilai path coefficients sebesar 0,522 menunjukkan efek moderasinya memperkuat hubungan $X_{1}$ (VAIC) dan $Y$ (TOBINS'Q).

4. ROA tidak memoderasi pengaruh $X_{2}(C G)$ terhadap $Y$ (TOBINS' $Q$ ) karena nilai $p$-values senilai 0,249 dimana lebih besar dari 0,05.

\section{E. KESIMPULAN}

Sesuai analisa dan pengujian yang sudah dijalankan oleh peneliti, dapat diambil kesimpulan jika intellectual capital memberi pengaruh yang positif serta signifikan pada nilai lembaga usaha yang bermakna apabila lembaga usaha mempunyai nilai intelektual kapital yang lebih besar maka lembaga usaha tersebut mempunyai keunggulan kompetitif yang mampu mengatasi ketatnya persaingan yang ada. Oleh karena itu nilai perusahaan akan semakin mengalami peningkatan. Corporate Governance tidak emberi pengaruh nilai lembaga usaha. Profitabilitas yang dilakukan proksi dengan ROA dapat memoderasi pengaruh intellectual capital pada nilai perusahaan. Profitabilitas yang diproksi dengan ROA tidak bisa melakukan moderasi pengaruh corporate governance terhadap nilai lembaga usaha.

Adapun saran dari penelitian ini, guna pengembangan penelitian selanjutnya adalah: Diharapkan penelitian selanjutnya agar mengembangkan variabel - variabel atau proksi yang lain sehingga dapat menambah literasi pembahasan dan variasi topik penelitian kedepannya. 
Diharapkan penelitian selanjutnya dapat menambahkan jumlah sampel dan menggunakan sampel penelitian yang tidak hanya terbatas pada perusahaan sektor perbankan saja, namun sektor - sektor lain yang terdaftar di BEl, sehingga dapat merepresentasikan pengaruh antar variabel yang lebih efektif.

\section{DAFTAR PUSTAKA}

Annisya, M., Lindrianasari, \& Asmaranti, Y. (2016). Mendeteksi Kecurangan Pelaporan Keuangan Memakai Fraud Diamond. Jurnal Bisnis Dan Ekonomi (JBE), 23(1), 72-89.

Arifardhani, Y. (2020). Hukum Pasar Modal Di Indonesia: Dalam Perkembangan (1st ed.). Kencana.

Chowdhury, L. A. M., Rana, T., \& Azim, M. I. (2019). Efisiensi Modal Intelektual dan Kinerja Organisasi dalam Konteks Industri Farmasi di Bangladesh. Jurnal Modal Intelektual, 20(6), 784-806. https://doi.org/10.1108/JIC-10-2018-0171

Davis, P. J., \& Simpson, E. (2017). Teori Berbasis Sumber Daya, Persaingan, dan Diferensiasi Staf di Afrika: Memanfaatkan Karyawan sebagai Sumber Keunggulan Kompetitif Berkelanjutan. American Journal of Management, 17(1), 19.

Devi, S. (2017). Analisa Dampak Tindakan Mengungkap Manajemen Risiko Perusahaan Serta Mengungkap Modal Intelektual Pada Nilai Lembaga Usaha. Jurnal Akuntansi Dan Keuangan Indonesia, 14(1), 20-45.

Lestari, D. A. D., \& Satyawan, M. D. (2019). Dampak Intellectual Capital pada Angka Industri Dengan Profitabilitas Selaku Variabel Moderasi.. Jurnal Akuntansi AKUNESA, 7(1), 122.

Hakim, L., Sunardi, N. (2017). Determinant of leverage and it's implication on company value of real estate and property sector listing in IDX period of 2011-2015. Man in India, 97(24), pp. 131-148.

Kadim, A., Sunardi, N \& Husain, T. (2020). The modeling firm's value based on financial ratios, intellectual capital and dividend policy.Accounting, 6(5), 859-870.

Husain, T., \& Sunardi, N. (2020). Firm's Value Prediction Based on Profitability Ratios and Dividend Policy. Finance \& Economics Review, 2(2), 13-26.

Nardi Sunardi Et Al (2020). Determinants of Debt Policy and Company's Performance, International Journal of Economics and Business Administration Volume VIII Issue 4, 204-213

Sunardi, N., \& Lesmana, R. (2020). Konsep Icepower (Wiramadu) sebagai Solusi Wirausaha menuju Desa Sejahtra Mandiri (DMS) pada Masa Pandemi Covid-19. JIMF (Jurnal IImiah Manajemen Forkamma), 4(1).

Nurhayati, S. (2017). Analisis Dampak Modal Intelektual Pada Kinerja Keuangan Serta Kinerja Pegawai Pada Lembaga Usaha Yang Ada Di BEI Priode 2010-2013. Jurnal ASET (Akuntansi Riset), 9(1), 133-172. Https://Doi.Org/10.17509/Jaset.V9i1.5260

Purnama, S. A., \& Rikumahu, B. (2020). Analisa Aspek Yang Memberi Pengaruh Pada Harga Saham Meakai Tehnik Analisis Komponen Utama (Kajian Di Lembaga Perbankan Yang Ada di BEI Priode 2015 - 2019). E-Proceeding of Management, 7(2), 
5240.

Putri, D. A., \& Yuliandhari, W. S. (2020). Pengaruh Rasio Kesehatan Lembaga Keuangan Memakai RGEC Pada Perkembangan Keuntungan. Jurnal Akuntansi Bisnis Dan Ekonomi (JABE), 6(1), 1569-1576.

Putri, I., \& Iramani, R. (2017). Kajian Tata Kelola Perusahaan Yang Baik Dan Kinerja Saham Perusahaan Terbuka Pada Lembaga Usaha Yang Menjalankan Usahanya Bidang Manufaktur Di Indonesia. Journal of Business \& Banking, 7(2), 177-192. https://doi.org/10.14414/jbb.v7i2.990

Sartono, A. (2010). Mangement Keuangan Teori serta Aplikasi. BPFE.

Safriliana, R., Subroto, B., Subekti, I., \& Fuad Rahman, A. (2018). Tinjauan tentang Contracting Theory dan Agency Theory: Determinan dari Switching Kantor Akuntan Publik Sukarela. KnE Social Sciences, 3(10), 292-302. https://doi.org/10.18502/kss.v3i10.3381

Sayyidah, U., \& Saifi, M. (2017). Analisa Dampak Modal Intelektual Pada Nilai Suatu Lembaga Usaha Dengan Tingkat Keuntungan Selaku Variabel Moderasi. Jurnal Administrasi Bisnis (JAB), 46(1), 163-171.

Soewarno, N., \& Tjahjadi, B. (2020). Tindakan Itu Penting: Investigasi Empiris Intellectual Capital dan Kinerja Keuangan Perusahaan Perbankan di Indonesia. Jurnal Modal Intelektual, 21(6), 1085-1106. https://doi.org/10.1108/JIC-09-2019-0225

Sugiyono. (2019). Metode Kajian Kuantitatif. Alfabeta.

Suhadak, Kurniaty, Handayani, S. R., \& Rahayu, S. M. (2019). Return Saham dan Kinerja Keuangan Sebagai Variabel Moderasi Dalam Pengaruh Good Corporate Governance Terhadap Nilai Perusahaan. Jurnal Riset Akuntansi Asia, 4(1), 18-34. https://doi.org/10.1108/ajar-07-2018-0021

Ulum, I. (2017). Kerangka Model Pengungkapan, Modal Intelektual Pengukuran Serta Kinerja Karyawan. UMM Press. 